\title{
БІОЛОГІЧНІ НАУКИ
}

UDC 575.11+577.21

\section{RECURRENT PREGNANCY LOSS ASSOCIATION WITH ALLELIC VARIANTS OF IL8 AND IL10 GENES}

\author{
(C) A. Kucherenko, R. Gulkovskyi, K. Khazhylenko, I. Vorobiova, T. Nakvasiuk, L. Livshits
}

The study evaluated IL8 -781C/T and IL10 -592C/A, -1082A/G polymorphisms association with recurrent pregnancy loss ( $R P L)$ ( $n=110$ case, $n=106$ control).

IL10 -592AA genotype and $-1082 A$ allele carriers frequency was higher in RPL group (6.6 \%, $87.3 \%$ ) comparing to control $(0.9 \%, 76.4 \%)$. The $-1082 \mathrm{~A}$ allele carriers have twice increased RPL risk $(O R=2.12$; CI95\%: 1,03-4,34).

Keywords: IL8 gene/ IL10 gene/ interleukin/recurrent pregnancy loss.

\begin{abstract}
У дослідженні оцінювали асоиіацію поліморфізмів генів IL8 -781C/T ma IL10 -592C/A, -1082A/G зі звичним невиношуванням вагітності (НВ) ( $n=110$ дослідна група, $n=106$ контроль).

Частота носіїв генотипа -592AA і алелю - 1082 А гена IL10 була вище в групі НВ (6,6 \%, 87,3\%) порівняно з контрольною (0,9\%, 76,4\%). Ризик невиношування у носіїв алелю -1082A вдвічі вище (OR = 2,12; CI95 $\%: 1,03-4,34)$.

Ключові слова: IL8 ген / IL10 ген / інтерлейкін / звичне невиношування вагітності.
\end{abstract}

\section{Introduction}

The loss of three or more sequential pregnancies in the first trimester of gestation is defined as recurrent pregnancy loss (RPL). Up to $5 \%$ of reproductive age women are affected by this pathology [1]. Amongst the variety of RPL etiologies (cytogenetic, endocrine, immunological, anatomical) the idiopathic is the most common [2]. Knowledge accumulation in this field made it clear that successful pregnancy is a result of dynamic interaction between immunological and immunogenetic factors. It was shown that the disruption of these networks may often result in reproductive failure [2]. Multiple studies confirmed that the maternal immune system is crucial for pregnancy establishment and maintenance [3]. Periods of pro-inflammatory and antiinflammatory environment prevalence in gestational tissues occur in precise sequence to provide pregnancy tolerance [4]. Cytokines are essential molecules to provide this type of interchange.

\section{Purpose}

The aim of this study was to evaluate the association of $I L 8$ gene $-781 \mathrm{C} / \mathrm{T}, I L 10$ gene $-592 \mathrm{C} / \mathrm{A}$ and $-1082 \mathrm{~A} / \mathrm{G}$ polymorphisms with RPL pathogenesis in group of patients from Ukraine.

\section{Literature review}

Cytokines are crucial participants in the processes of gametogenesis, implantation, trophoblast invasion, placental development and immunological tolerance of fetus [2]. In particular, pro-inflammatory cytokines (IL-1, IL-6, IL-8, IL-15) promote cytotrophoblast invasion of decidua, inflammatory and embriotoxic reaction. On the other hand, anti-inflammatory cytokines (IL-4, IL-10) prevent embriotoxic reaction of mother's organism [3]. One of the primary factors affecting cytokine network function is altered regulation of respective genes expression. Numerous studies were concentrated on the impact of allelic variants in cytokine genes on their expression and, as a result, the association of some polymorphisms with pathologies [5-7].

Chemokine IL- 8 is a crucial player in the process of implantation. It promotes trophoblastic cells migration and invasion [8]. IL8 gene is located on chromosome 4 in position $4 \mathrm{q} 13-\mathrm{q} 21$. It consists of 4 exons and 3 introns and encloses 235 SNPs [9]. 3'-UTR region and intron 1 are the most enriched with SNPs [9]. Interleukin 10 is an anti-inflammatory cytokine which is a major suppressor of embryo elimination and a promoter of trophoblastic growth [3]. IL10 gene is located on chromosome 1 in position 1q31-q32. It consists of 5 exons and 4 introns. The total amount of 187 SNPs is reported for this gene, predominantly located inside intron 1 and within $2 \mathrm{~Kb}$ prior to coding region (including promoter region [10]. Several SNPs have been reported to influence IL8 and IL10 gene expression $[11,12]$. Some of them were found to be associated with reproductive pathologies, though these data remain controversial and require further investigation [13].

\section{IL8 and IL10 variants association with RPL}

A case group comprised 110 unrelated women with history of idiopathic RPL (at least two cases of consequent miscarriage in the first trimester), patients of 
the SI "Institute of Pediatrics, Obstetrics and Gynecology of NAMS of Ukraine" (aged 34,15 + 4,49 years; fetal losses $2,73+0,87$; parity $0,29+0,55)$. In order to exclude other possible risk factors but immunogenetic the patients underwent thorough examinations and only the patients with following clinical features were chosen for the investigation: no family history of birth defects; no genital tract anatomic abnormalities (confirmed by ultrasonography or hysterosalpingography); no common immunologic risk factors (anti-nuclear antibodies, antiphospholipid antibodies, lupus anticoagulant), defects of thyroid function, diabetes mellitus, hyperprolactinemia and infections such as chlamydia; neither inherited nor acquired thrombophilia, no Leiden (F5 G1691A) and the prothrombin gene mutations ( $F 2$ G20210A); normal karyotype of both patients and their partners (though not all the abortuses underwent cytogenetic analysis).

A control group consisted of 106 unrelated healthy women (aged 26,23 $\pm 2,99$ years) with no history of RPL, who have given birth to at least one child conceived in natural way. All participants have given their informed consent prior to clinical examination and genotyping.
The study was approved by The Bioethical Committee of Institute of Molecular Biology and Genetics of NAS of Ukraine.

The material of the study was genomic DNA extracted from peripheral blood samples of patients and control group individuals using standard phenolchloroform technique. Genotyping for $I L 8$ gene $-781 \mathrm{C} / \mathrm{T}$, IL10 gene $-592 \mathrm{C} / \mathrm{A}$ and $-1082 \mathrm{~A} / \mathrm{G}$ polymorphic variants was performed by a PCR-based restriction fragment length polymorphism assay as described previously [11, 14]. Statistical analysis has been performed using GenePop and OpenEpi statistical packages [15, 16]. Fisher's exact test (Mid-P method) was used to estimate the difference in genotype and allelic distribution. In order to assess the association of certain genotype with RPL, OR index was calculated. A P-value of less than 0.05 was regarded as significant.

The results of genotyping for both studied polymorphic variants are presented in Table 1. Genotype frequencies for all studied variants showed no significant deviation from the ones expected according to HardyWeinberg equilibrium.

Table 1

Genotype and allelic distribution of $I L 8$ gene $-781 \mathrm{C} / \mathrm{T}, I L 10$ gene $-592 \mathrm{C} / \mathrm{A}$ and $-1082 \mathrm{~A} / \mathrm{G}$ gene polymorphic variants in studied groups

\begin{tabular}{|c|c|c|c|c|c|c|c|}
\hline Locus & & RPL group, $\mathrm{n}$ & $\begin{array}{c}\text { RPL group, } \\
\%\end{array}$ & $\begin{array}{l}\text { Control } \\
\text { group, } \mathrm{n}\end{array}$ & $\begin{array}{c}\text { Control } \\
\text { group, } \%\end{array}$ & OR & CI 95\% \\
\hline \multirow{7}{*}{$I L 8-781 \mathrm{C} / \mathrm{T}$} & \multicolumn{7}{|c|}{ Genotype } \\
\hline & $\mathrm{CC}$ & 38 & 34,5 & 18 & 16,9 & \multirow{2}{*}{5,06} & \multirow{2}{*}{$2,56-9,99$} \\
\hline & $\mathrm{CT}$ & 58 & 52,7 & 43 & 40,6 & & \\
\hline & $\mathrm{TT}$ & 14 & 12,7 & 45 & 42,5 & 0,20 & $0,10-0,39$ \\
\hline & \multicolumn{7}{|c|}{ Allele } \\
\hline & $\mathrm{C}$ & 134 & 60,9 & 79 & 37,3 & - & - \\
\hline & $\mathrm{T}$ & 86 & 39,1 & 133 & 62,7 & - & - \\
\hline \multirow{7}{*}{ IL $10-592 \mathrm{C} / \mathrm{A}$} & \multicolumn{7}{|c|}{ Genotype } \\
\hline & $\mathrm{CC}$ & 63 & 57,3 & 70 & 66,1 & 0,69 & $0,40-1,20$ \\
\hline & $\mathrm{CA}$ & 40 & 36,4 & 35 & 33,0 & 1,16 & $0,66-2,03$ \\
\hline & AA & 7 & 6,4 & 1 & 0,9 & 7,14 & $0,86-59,03$ \\
\hline & \multicolumn{7}{|c|}{ Allele } \\
\hline & $\mathrm{C}$ & 166 & 75,5 & 175 & 82,5 & - & - \\
\hline & A & 54 & 24,5 & 37 & 17,5 & - & - \\
\hline \multirow{7}{*}{$I L 10-1082 \mathrm{~A} / \mathrm{G}$} & \multicolumn{7}{|c|}{ Genotype } \\
\hline & $\mathrm{AA}$ & 35 & 31,8 & 23 & 21,7 & \multirow{2}{*}{2,12} & \multirow{2}{*}{$1,03-4,34$} \\
\hline & $\mathrm{AG}$ & 61 & 55,5 & 58 & 54,7 & & \\
\hline & GG & 14 & 12,7 & 25 & 23,6 & 0,47 & $0,23-0,97$ \\
\hline & \multicolumn{7}{|c|}{ Allele } \\
\hline & A & 131 & 59,5 & 104 & 50,9 & - & - \\
\hline & $\mathrm{G}$ & 89 & 40,5 & 108 & 49,1 & - & - \\
\hline
\end{tabular}


No difference was found in $I L 8$ gene $-781 \mathrm{C} / \mathrm{T}$ genotype distribution in studied groups. As to $I L 10$ gene polymorphic variants, frequency of individuals with 592AA genotype was significantly higher in RPL group $(6,6 \%)$ comparing to control group $(0,9 \%)$. Frequency of IL10 gene -1082A allele carriers was significantly higher in group of patients with RPL (87,3\%) comparing to control group $(74,6 \%)$. The $-1082 \mathrm{~A}$ allele carriers have RPL risk increased up to 2-fold $(\mathrm{OR}=2,12$; CI 95 $\%: 1,03-4,34)$. Obtained results are supported by the existing knowledge of immunological processes during early stages of gestation.

The greatest challenge to the maternal immune response occurs at the outset of pregnancy, when the embryo implants into the maternal endometrium and development of the placenta commences. The inflammation process is crucial during this stage as it facilitates the process of implantation [17]. On the other hand, unbalanced inflammation during early stages of gestation may lead to negative consequences. IL-10 appears to be the most powerful immunosuppressive factor produced locally in gestational tissues [18, 19]. Studies on human decidua and endometrium have shown negative effect of IL-10 deficit on pregnancy maintenance [20]. Knock-out studies on mice models have established increased rate of fetal resorption and higher susceptibility of developing fetus to pathogens [21]. Additionally IL-10 injection prevents fetal loss in abortion-prone mice [22]. As alterations in IL-10 production became evident to correlate with pregnancy outcome it has been suggested that certain IL10 genotypes may be associated with higher risk of RPL. Impact on expression is studied to be the best for polymorphic variants $-592 \mathrm{C} / \mathrm{A}$ and $-1082 \mathrm{~A} / \mathrm{G}$. Alleles 592A and -1082A are associated with lower IL-10 production [12]. Both these polymorphic variants were studied for association with RPL in individual studies and meta-analysis but the results turned out to be controversial [13]. Partly this ambiguity may result from heterogeneity of case groups. The results of this study are consistent with multiple evidence of low-production phenotype negative impact on pregnancy outcome. Women with IL10 gene -592AA, -1082AG and -1082AA genotypes may have fewer chances for pregnancy maintenance during early stages of gestation.

\section{Conclusions}

Despite the significant achievements in understanding the immunological features of pregnancy development many controversial issues are yet to be clarified. However, on the basis of statistically significant differences in genotype distribution established in this study, IL10 gene -592AA genotype and -1082A allele may be considered the markers of increased RPL risk.

\section{Funding}

This work was supported by the National Academy of Sciences of Ukraine [grant number 0110U000695]; and the National Academy of Medical Sciences of Ukraine [grant number U002127].

\section{References}

1. Branch, D.W. Clinical practice. Recurrent miscarriage [Text] / D.W. Branch, M. Gibson, R.M. Silver // New England Journal of Medicine. - 2010. - Vol. 363, Issue 18. - P. 1740-1747. doi: 10.1056/NEJMcp1005330

2. Lim, K. J. H. Cytokines and immuno-endocrine factors in recurrent miscarriage [Text] / K. J. H. Lim, O. A. Odukoya, T. C. Li, I. D. Cooke // Human Reproduction Update. - 1996. - Vol. 2, Issue 6. - P. 469-481. doi: 10.1093/humupd/2.6.469

3. Saini, V. Cytokines in recurrent pregnancy loss [Text] / V. Saini, S. Arora, A. Yadav, J. Bhattacharjee // Clinica Chimica Acta. - 2011. - Vol. 412, Issue 9-10. - P. 702-708. doi: $10.1016 /$ j.cca.2011.01.002

4. Dealtry, G. B. The Th2 cytokine environment of the placenta [Text] / G. B. Dealtry, M. K. O'Farrell, N. Fernandez // International Archives of Allergy and Immunology. - 2000. Vol. 123, Issue 2. - P. 107-119. doi: 10.2165/00129785200202010-00002

5. Daly, A. K. Polymorphisms in immunoregulatory genes: towards individualized immunosuppressive therapy? [Text] / A. K. Daly, C.P. Day, P. T. Donaldson // American Journal of Pharmacogenomics. - 2002. - Vol. 2, Issue 1 P. 13-23. doi: 10.2165/00129785-200202010-00002

6. Emonts, M. Polymorphisms in genes controlling inflammation and tissue repair in rheumatoid arthritis: a case control study [Text] / M. Emonts, M. J. Hazes, J. J. HouwingDuistermaat, C. E. van der Gaast-de Jongh, L. de Vogel, H. K. Han, J. M. Wouters, J. D. Laman, R. J. Dolhain // BMC Medical Genetics. - 2011. - Vol. 12, Issue 1. - P. 36. doi: 10.1186/1471-2350-12-36

7. Heinzmann, A. Association study suggests opposite effects of polymorphisms within IL8 on bronchial asthma and respiratory syncytial virus bronchiolitis [Text] / A. Heinzmann, I. Ahlert, T. Kurz, R. Berner ,K. A. Deichmann // Journal of Allergy and Clinical Immunology. - 2004. - Vol. 114, Issue 3. - P. 671-676. doi: 10.1016/j.jaci.2004.06.038

8. Weimar, C. H. The motile and invasive capacity of human endometrial stromal cells: implications for normal and impaired reproductive function [Text] / C. H. Weimar, N. S. Macklon, E. D. Post Uiterweer, J. J. Brosens, B. Gellersen // Human Reproduction Update. - 2013. - Vol. 19, Issue 5. - P. 542-557. doi: 10.1093/humupd/dmt025

9. The GeneCards human gene [Electronic resource]/ Available at: http://www.genecards.org/cgibin/carddisp.pl?gene $=$ il

10. The GeneCards human gene [Electronic resource] / Available at: http://www.genecards.org/cgibin/carddisp.pl?gene=il10

11. Hacking, D. Increased in vivo transcription of an IL8 haplotype associated with respiratory syncytial virus diseasesusceptibility [Text] / D. Hacking, J. C. Knight, K. Rockett, H. Brown, J. Frampton, D. P. Kwiatkowski, J. Hull, I. A. Udalova // Genes Immun. - 2004. - Vol. 5, Issue 4. - P. 274-282. doi: 10.1038/sj.gene.6364067

12. Temple, S. E. Alleles carried at positions -819 and 592 of the IL10 promoter affect transcription following stimulation of peripheral blood cells with Streptococcus pneumonia [Text] / S. E. Temple, E. Lim, K. Y. Cheong, C. A. Almeida, P. Price, K. G. Ardlie, G. W. Waterer // Immunogenetics. - 2003. - Vol. 55, Issue 9. - P. 629-632. doi: 10.1007/s00251-003-0621-6

13. Choi, Y. K. Cytokine gene polymorphisms in recurrent spontaneous abortions: a comprehensive review [Text] / Y. K. Choi, J. Kwak-Kim // American Journal of Reproductive Immunology. - 2008. - Vol. 60, Issue 2. - P. 91110. doi: $10.1111 /$ j.1600-0897.2008.00602.x 
14. Costa, G. C. Functional IL-10 gene polymorphism is associated with Chagas disease cardiomyopathy [Text] / G. C. Costa, M. O. da Costa Rocha, P. R. Moreira, C. A. Menezes, M. R. Silva, K. J. Gollob, W. O. Dutra // Journal of Infectious Diseases. - 2009. - Vol. 199, Issue 3. - P. 451-454. doi: $10.1086 / 596061$

15. Rousset, F. Genepop'007: a complete reimplementation of the Genepop software for Windows and Linux [Text] / F. Rousset // Molecular Ecology Resources. 2008. - Vol. 8, Issue 1. - P. 103-106. doi: 10.1111/j.14718286.2007.01931.x

16. Sullivan, K. M. OpenEpi: a web-based epidemiologic and statistical calculator for public health [Text] / K. M. Sullivan, A. Dean, M. M. Soe // Public Health Reports. - 2009. - Vol. 124, Issue 3. - P. 471-474.

17. Saito, S. Th1/Th2/Th17 and regulatory T-cell paradigm in pregnancy [Text] / S. Saito, A. Nakashima, T. Shima, M. Ito // American Journal of Reproductive Immunology. - 2010. - Vol. 63, Issue 6. - P. 601-610. doi: 10.1111/j.1600-0897.2010.00852.x

18. Krieg, S. A. Global alteration in gene expression profiles of deciduas from women with idiopathic recurrent pregnancy loss [Text] / S. A. Krieg, X. Fan, Y. Hong, Q. X. Sang, A. Giaccia, L. M. Westphal, R. B. Lathi, A. J. Krieg, N. R. Nayak // Molecular Human Reproduction. 2012. - Vol. 18, Issue 9. - P. 442-450. doi: $10.1093 / \mathrm{molehr} /$ gas017
19. Morelli, S. S. Early serum interleukin-8 evaluation may prove useful in localizing abnormally implanted human gestations after in vitro fertilization [Text] / S. S. Morelli, D. A. Keegan, L. C. Krey, J. Katz, M. Liu, N. Noyes // Fertility and Sterility. - 2008. - Vol. 90, Issue 6. - P. 2068-2072. doi: 10.1016/j.fertnstert.2007.10.063

20. Piccinni, M. P. Defective production of both leukemia inhibitory factor and type 2 T-helper cytokines by decidual $\mathrm{T}$ cells in unexplained recurrent abortions [Text] / M. P. Piccinni, L. Beloni, C. Livi , E. Maggi, G. Scarselli, S. Romagnani // Nature Medicine. - 1998. - Vol. 4, Issue 9. P. $1020-1024$. doi: $10.1038 / 2006$

21. Robertson, S. A. Interleukin 10 regulates inflammatory cytokine synthesis to protect against lipopolysaccharide-induced abortion and fetal growth restriction in mice [Text] / S. A. Robertson, A. S. Care, R. J. Skinner // Biology of Reproduction. - 2007. - Vol. 76, Issue 5. - P. 738-748. doi: 10.1095/biolreprod.106.056143

22. Chaouat, G. IL-10 prevents naturally occurring fetal loss in the CBA $x \mathrm{DBA} / 2$ mating combination, and local defect in IL-10 production in this abortion-prone combination is corrected by in vivo injection of IFN-tau [Text] / G. Chaouat, A. Assal Meliani, J. Martal, R. Raghupathy, J. F. Elliott, T. Mosmann, T. G. Wegmann // The Journal of Immunology. 1995. - Vol. 154, Issue 9. - P. 4261-4268.

Дата надходження рукопису 15.08.2014

Kucherenko Anastasiia, PhD student, junior research fellow, Department of general and molecular genetics, Educational and Scientific Centre «Institute of Biology», Taras Shevchenko National University of Kyiv Glushkova ave., Kyiv, Ukraine, 03022. Human genomics department, Institute of Molecular Biology and Genetics of NAS of Ukraine, 150 Zabolotnogo str., Kyiv, Ukraine, 03680.

E-mail: kucherenko.a.m@gmail.com

Gulkovskyi Roman, PhD student, junior research fellow, Department of general and molecular genetics, Educational and Scientific Centre «Institute of Biology», Taras Shevchenko National University of Kyiv, Glushkova ave., Kyiv, Ukraine, 03022, Human genomics department, Institute of Molecular Biology and Genetics of NAS of Ukraine, 150 Zabolotnogo str., Kyiv, Ukraine, 03680.

E-mail: falko0grv@gmail.com

Khazhylenko Kseniya, obstetrician/gynecologist of Superior Expert Category, geneticist, Obstetric gynecological clinic "ISIDA", 65, Lepse blvd, Kyiv, Ukraine, 03000.

E-mail: k_khazhylenko@isida.ua

Vorobiova Iryna, M.D., obstetrician/gynecologist of Superior Expert Category, Head of the Department Department of scientific problems of pregnancy loss, SI "Institute of Pediatrics, Obstetrics and Gynecology of NAMS of Ukraine", 8 Maiborody str., Kyiv, Ukraine, 04050.

E-mail: doctor.56@bk.ru

Nakvasiuk Tamara, PhD student, Department of scientific problems of pregnancy loss, SI "Institute of Pediatrics, Obstetrics and Gynecology of NAMS of Ukraine", 8 Maiborody str., Kyiv, Ukraine, 04050. E-mail: tamara.nakvasiuk@gmail.com

Livshits Ludmila, PhD, Professor, Head of the Department, Human genomics department, Institute of Molecular Biology and Genetics of NAS of Ukraine, 150 Zabolotnogo str., Kyiv, Ukraine, 03680.

E-mail: ludmila.imbg@gmail.com 